\title{
Suffering for the Suffering of the Other: A Levinasian Approach to Immigration
}

\author{
Jorge Medina \\ School of Philosophy, UPAEP University, 21 sur 1103, Puebla, Pue. México \\ E-mail: jorge.medina@upaep.mx \\ Juan Pablo Aranda \\ School of Politics, UPAEP University, 21 sur 1103, Puebla, Pue. México \\ E-mail: juanpablo.aranda@upaep.mx
}

\begin{abstract}
Rather than trying to justify pain and suffering in terms of a general theory of necessity in which individual pain becomes intelligible and senseful only in the narrative of the whole, as in Leibniz' Theodicy, Emmanuel Levinas asserts that suffering is "useless." Against theodicy, Levinas defends the insurmountable futility and absurdity of pain, a paradigmatic example of which is found in the concentration camps. We must therefore choose, Levinas asserts, either theodicy or ethics. This approach makes the subject very significant, since it encourages activity and responsibility in the face of a possible passivity and indifference towards others. This approach makes the subject very significant, since it encourages activity and responsibility instead of passivity and indifference towards others. In trying to understand how to restore meaning to suffering, Levinas offers a typology of the sources of suffering: sins of commission, sins of omission, and suffering the other's suffering because of love. In order to illustrate the ethical dynamics of suffering, we analyze the contemporary situation of immigration, rejecting the case for open borders as failing to offer a restitution for the suffering caused.
\end{abstract}

Keywords: Levinas. Theodicy. Ethics. Suffering. Vulnerability. Immigration.

DOI: $10.7176 / \mathrm{JPCR} / 49-05$

Publication date:June 30th 2020

\section{Introduction}

Both in misery and misfortune, there is something beyond mere pain. Phenomenologically, suffering is often experienced as the verification of nonsense. Some philosophers, however, have pretended that suffering can be endured by means of the conviction that there is in existence a blind need that produces meaning at a superior level. In "Useless Suffering" (Entre nous), Emmanuel Levinas harshly criticizes this position which is singularly expounded by Leibniz in his Theodicy.

Admitting that theodicy is an exit to nonsense implies acknowledging that there is a pedagogy of pain and that, just as the body has an alarm system to address a health risk -and the same would happen with the punishment of the guilty in so far as it favors health of the collective-, suffering teach us the correct attitude towards life.

The risk of a theodicy is the subordination of suffering to health, be it corporal or spiritual, individual or collective, temporary or eternal, thus suppressing the features that a phenomenological approach to suffering gives us: "it is an in-spite-of-consciousness, the unassumable" (Levinas 1998: 91). Besides, according to Levinas, this kind of justification of my neighbor's suffering would be at the origin of all immorality.

The suffering I experience is, according to Levinas, 'useless', but when I willingly suffer myself because of the suffering of the other -the climax of her vulnerability- then my suffering acquires meaning and motivates action. The vulnerability of those who suffer in society -immigrants (forced migration) are a paradigmatic casedoes not call us to compassion but rather judges our existence, blaming us beforehand. The suffering of the innocent is not overcome in interiority, but in exteriority, in praxis. The vulnerability of the suffering other then becomes the principle by means of which the self is identified, and makes it respond in the first person, turning it into a non-transferable subjectivity in the face of misery. Suffering by the useless suffering of the other -what we will call hyperbolic vulnerability- will be presented here as a way of approaching ethical subjectivity.

\section{Levinas' argument in "Useless suffering"}

Levinas divides his essay "Useless Suffering” into four sections: Phenomenology; Theodicy; The End of Theodicy; and The Interhuman Order.

In the first section, Levinas offers a fine phenomenological analysis of suffering. For him suffering is ambiguous, it is even a "contradiction qua sensation: the ache of pain -woe" (Levinas 1998: 92). For suffering, on the one hand, is a datum of consciousness, a fact of experience, a psychological 'content', a sensation. On the other hand, suffering is experienced as intolerable not because of its degree of intensity but because it repels us. This repulsion is the very opposite of the unifying effect of Kant's 'I think', because suffering is disruptive; indeed, it disrupts our very subjectivity. 
Some passive experiences involve activity; the senses, for example, are passive yet active in their receiving. Suffering, on the contrary, is but an undergoing with no semblance of activity; it is a 'no' that we cry out with our whole being, it is our vulnerability, our trial, overwhelming us by its violence and cruelty. "The evil of pain, the deleterious per se, is the outburst and deepest expression, so to speak, of absurdity" (Levinas 1998: 93), hence it strikes us as something 'use-less', 'sense-less', and 'worth-less'.

Suffering seems especially 'useless' in small children or the mentally handicapped. They cannot console themselves by explaining away their suffering (even if there were reasons at hand) or by sighting their anguish and helplessness from 'new perspectives'. The cry, the pleading, the sighs of someone in senseless pain means basically that he is asking for my help; it opens me up to some 'beyond' that for her signifies salvation. If the other's suffering made sense to me, I could file it under some heading, make it a part of some theory that would push me aside and leave me indifferent... and in 'peace'. But I feel it is my duty to help him in his senseless and useless pain, since in my experience "the anthropological category of the medical, a category that is primordial, irreducible and ethical, imposes itself" (Levinas 1998: 93). This opening -which supposes the other's suffering and makes a claim upon me- presupposes a human encounter between us wherein we envision together a pure suffering 'beyond' us. The face of the sufferer is what first alerts me and accuses me, pursuing me until I suffer his suffering, and thus come to feel "the just suffering in me for the unjustifiable suffering of the other" (Levinas 1998: 94). My suffering the other's suffering challenges me to care for her: "the consciousness of this inescapable obligation brings us close to God in a more difficult, but also a more spiritual, way than does confidence in any kind of theodicy" (Levinas 1998: 94).

In the second section, "Theodicy", Levinas notes that in its ambiguity suffering is a pattern, a content, but one that can be combined with other contents that make it reasonable and meaningful. And so, while suffering in itself seems senseless to us, when merged with these other contents, it may appear to us as rational and beneficial in at least five ways, offering: a) a juridical benefit, as deserved punishment, the wages of sin, fulfillment of justice; b) a pedagogical benefit, in the sense that the achievement of a labor makes up for the effort and fatigue behind it; c) a biological benefit, as a warning sign, say, of a health problem, showing that we have too little of what we need or too much of what we do not need; d) a social benefit, in the sense that suffering shapes our character by preparing us to accept the cost of living in community with an eye to its greater benefits, as well as to be more tolerant towards 'difficult' people; e) a sapiential benefit, as the price to be paid for spiritual maturity and wisdom (Ecl 1,18 ), because a person who recognizes the causes of moral evil she and others face will suffer more than those ignorant of them, because she who knows the risks of the world can experience fear, and because she who knows what the human heart is capable of will anticipate the sorrows that will come upon her.

Why, then, do we need a theodicy to make sense of suffering since apparently we can understand it with the help of other factors in some teleological theory? Levinas answers by recalling those cases where suffering seems most useless: the affliction of the mentally handicapped, the unjust oppression of the weak, war crimes against the innocent, the scourges of nature that affect the righteous. In these cases, it seems, we cannot see any juridical, pedagogical, biological, social or sapiential benefits. This is why Leibniz -as well as some ancient exegetessought explanations outside of these particular circumstances. Rather, he said, the 'grand design' of the universe, or of history, would explain how a particular evil serves the good of the whole, thus surpassing the absurdity of suffering by incorporating in a general narrative. Metaphysical finality, then, counters any attempt of seeing suffering as useless. Theodicy "is the grand idea necessary to the inner peace of souls in our distressed world" (Levinas 1998: 96).

The third section is entitled "The end of theodicy". Lying in the background is the question: does the metaphysics of theodicy really console us, or, if it does not, would it justify barbarous behavior and anesthetize our conscience? The twentieth century upset the balance between the different kinds of suffering and their explanations, which had seemed valid since the Enlightenment. There were sufferings 'out of kilter' with the 'overall plan' that were supposed to explain them. And although Levinas mentions a number of these kinds of suffering, with Emil Fackenheim he sees Auschwitz as the paradigmatic case: it is the gratuitous suffering, unjustified, that makes all explanation odious. The Holocaust, which stands out in the history of human cruelty for the uniqueness both of the crime and of the victim, has taught us that not every evil is sought for the sake of a good, as the scholastics believed, but that evil for the sake of evil, annihilation for the sake the annihilation itself, is also a human possibility.

Reflecting on the term 'Holocaust' Giorgio Agamben leans on Primo Levi's utter rejection of any attempt to justify what is essentially unimaginable: "I am irritated by the attempts of some religious extremists to interpret the extermination according to the manner of the prophets: as a punishment for our sins. No! I do not accept this. What is terrifying is that it was senseless..." (Levi 1997: 219). For Agamben, "what appears in the camp is an extermination for which it may be possible to find precedents, but whose forms make it absolutely senseless." He adds some lines below: "The unfortunate term 'holocaust' (usually with capital ' $\mathrm{H}$ ') arises from this unconscious demand to justify a death that is sine causa-to give meaning back to what seemed incomprehensible" (1999: 2728). 
If Auschwitz can be justified or understood, we can therefore understand all our misery and justify every illness, every injustice and every war. On the contrary, by means of a reduction to absurdity we reach the conclusion that if Auschwitz is meaningless, then theodicy should be declared demised, for otherwise "the justification of the neighbor's pain" certainly becomes "the source of all immorality" (Levinas 1998: 99). We must therefore choose either theodicy or ethics. If we pick ethics, then we must again ask: what meaning does useless suffering have after Auschwitz?

Perhaps the Jewish people will give us an answer to our earlier question. The faithfulness of the Jews after the crimes of the Second World War is practically an imperative; it should be preserved with a rite, a tradition, a significance "in order not to be made accomplices of a diabolical project. Jews, after Auschwitz, are pledged to their faithfulness to Judaism and to the material and even political conditions of its existence" (Levinas 1998: 99). If we disregard for a moment the nationalistic rhetoric of the mandate, we can find in it a powerful truth for humanity: we cannot be indifferent and abandon the world to useless suffering; rather, since we are now unable to fit everything into some theory, we must respond to "a history that now demands even more from the resources of the $I$ in each one of us, and from its suffering inspired by the suffering of the other, from its compassion which is a non-useless suffering (or love), which is no longer suffering 'for nothing' and immediately has meaning" (Levinas 1998: 100).

Finally, in the fourth section, "The interhuman order", Levinas states more clearly the conclusions already implicit in the third: $(a)$ we must restore to suffering its meaningful dimensions; after the demise of theodicy we can do this only from an interhuman standpoint, that is: from being useless suffering in the other to be meaningful for me; $(b)$ we can lose this interhuman perspective in the political arena, where its impersonal laws and its institutions stress reciprocity over altruism; we must bear in mind that impartiality and a lack of indifference lie at the base of this perspective; and $(c)$ the 'radiant otherness' of other people can become a mere show of good manners, or else it can rather grow into "my responsibility for the other, without concern for reciprocity, in my call for his or her disinterested help, in the asymmetry of the relation of one to the other" (Levinas 1998: 101).

\section{Love and the meaning of suffering}

To illustrate his notion of useless suffering, the basic senselessness behind suffering, Levinas offers two paradigms: that of the mentally disabled and that of those suffering from painful illnesses. Indeed, in order to show that pain or suffering is found in a 'pure' state, we must either isolate suffering from other contents of consciousness that adulterate or mesh it with a variety of meanings, as happens in the former case, or else we must see it as the central phenomenon of the illness that absorbs all other factors -instead of alleviating suffering, this only adds to the anguish and helplessness, as happens in the second case.

Around 1923, Husserl too saw the possibility of ethical action in 'meaningless' situations. "How is this so when we think of a mother who cares lovingly for her child? She may know that the world is 'meaningless', that tomorrow another flood could wipe out all our 'values.' She could be convinced that, though unlikely, something like it could happen 'some day,' and so, if a new world of values were to come about, the same thing would happen, and so no lasting value would remain and everything would end in a chaos destitute of all value. This true mother would say in the face of all this: 'that is as may be, but however certain it is, it is a thousand times more certain that I ought not to abandon my child, that I ought to care for him lovingly, and that his growth in body and soul, hence his well-being, is an absolute value that I choose as my goal. If I live in accord with this goal, only to that extent will I be good and faithful to my duty, and this is and always will be good, whether or not the world should turn out to have meaning or not"" (Husserl 2009: 803).

The senselessness of pain prompts the doctor to cure his patient or alleviate his pain. Now, such a cure $(\theta \varepsilon \rho \alpha \pi \varepsilon i ́ \alpha)$ can be given in two ways: either by alleviating the pain of the body through medical practice $(\pi \rho \tilde{\alpha} \xi 1 \varsigma)$, or by offering the soul sound reasons ( $\theta \varepsilon \omega \rho i \alpha)$ and meaning. The second way is found not in Leibniz but in Plato, who has given us an important precedent. In the dialogue with Charmides (157a), the therapeutic theory of Zalmoxis is discussed: we should not try to cure the eyes without the head nor the head without the body, nor the body without the soul. "And the treatment of the soul, so he said, my wonderful friend, is by means of certain charms, and these charms are words of the right sort: by the use of such words is temperance engendered in our souls".

The question is whether the senselessness behind the unjust suffering of another person can be cured with a theory that downplays its absurdity, or rather whether her suffering urges us who see her pain to help her or offer her immediate medical attention. Levinas agrees with this second option when he opposes a theodicy which would make useful the useless or bestow meaning on the meaningless. For from the viewpoint of the helpless victims of the Holocaust, there can be no explanation or justification. As Serrano (2010: 456) points out: "the almost infinite number of descriptions of Auschwitz can in no way be tied down to some 'perverseness of the heart' which -as Kant said- ever leads people to follow selfish maxims of action which usually (if not always) incline them practically to make their own interest the chief criterion of their behavior. In other words, the systematic killing in the extermination camps and the daily torture in the concentration camps cannot be reduced to some vague spate 
of selfishness or to a blind struggle for survival". The evil of the Holocaust is inordinate excessive not because of the killing methods it worked out, but because it cannot be 'assimilated' to any perspective (Levinas 1998b: 173).

And if for the sufferer her suffering cannot be assimilated to anything, neither can it be assimilated for the person who heeds her suffering. The other's pain is my pain; her suffering makes me suffer. Husserl correctly asserts that "we do not only live beside the other but in the other" (Husserl 2009: 805); in our closeness there is a kind of intimacy wherein the lack of indifference and the responsibility also cause suffering. But this suffering is no longer useless or absurd, since it has a meaning: being-for-the-other. For this reason, Levinas does not hesitate to call it 'inspired suffering', 'non-useless suffering', 'love', and in this he is also following his teacher Husserl, who said: "if adversity comes, the painful, the sorrowful, I cannot simply make it go away, least of all by not looking at it; perhaps I should not avoid it in any way, as is clear in cases of noble sorrow that it is my duty to suffer negatively" (Husserl 2009: 819).

How can we restore meaning to suffering without returning to theodicy? The answer is ethics. Footnotes 3 and 4 of the text analyzed by Levinas suggest a deeper understanding. On the one hand we have the great influence of Dostoyevsky, for whom there is a happy suffering, a sacrificial suffering of the person who suffers for others. There is, on the other hand, a hypothesis in the Talmud that speaks of "afflictions or sufferings of love" (yesurin shel ahava [יסורין של אהבה]), inspired of course in Scripture (Cant 2,5; Dt 8,3).

Dostoyevsky describes how the starets Zossima, when relating the life of his brother Markel who, sick and now bed-ridden, would say to his mother: "Mother, my little heart, in truth we are each responsible to all for all, it's only that men don't know this. If they knew it, the world would be a paradise at once'. 'God, can that too be false?' I thought as I wept. 'In truth, perhaps, I am more than all others responsible for all, a greater sinner than all men in the world"' (2009: 377). This teaching would come alive when Alyosha heard her brother Dmitri saying "Because we are all responsible for all. For all the 'babes,' for there are big children as well as little children All are 'babes.' I go for all, because someone must go for all. I didn't kill father, but I've got to go. I accept it." (2009: 765). For Levinas, the responsibility that Markel, just as Dmitri, understood and made his own is choice, as the responsible person can and should stand for everybody; still, nobody can take his own place in his task. Choice is not a privilege but a basic feature of the person, a principle of individuation making the subject unique among others. Levinas sees in some way that Dostoyevsky is suggesting the 'keeper' that Cain is not: one who himself is concerned for the other without understanding why: "It is like a despite myself that is more me [moi] than myself: it is an election. Every me is elected or chosen: no one else can do what it must do. This is the meaning of 'and I more than all the others' in Dostoyevsky" (Levinas 2000: 187).

Indeed, for Levinas guilt begins not in the present but in an immemorial past (for does not the past suffering of the other come before my sorrow for her?); the present does not exempt me from the responsibility for my neighbor that I cannot escape: choice and asymmetry become my vocation, as he affirms: "before the pair freedom/nonfreedom, a vocation is set up that goes beyond the limited and egoistic designs of the one who is only for-himself and who washes his hands of the misfortune and offenses that did not begin in his present time" (Levinas 2000: 175). Each of us stands before the other as guilty, stands before her freely -in the absence of proofs and outside verdicts- guilty even for the fault that she did not commit (Levinas 1998: 107). Now, this state of prehistoric guilt that weighs down the 'I' and constantly makes it a hostage of the other has in Dostoyevsky an ethical-religious meaning expressed by the Russian word nadryv, meaning immolation, self-sacrifice, martyrdom. Dmitri and in him anyone who has had an 'inspired suffering' accepts his undeserved punishment and, in a mystical ecstasy, wishes to be the one standing for all, burdened with all for his own good. This idea is closely related to Joseph Ratzinger's (1995: 72) understanding of the Christian notion of 'original sin' as a rejection of relationality, as the refusal to acknowledge our essential incompleteness, our need for God: "sin begets sin... all the sins of history are interlinked. Theology refers to this state of affairs by the certainly misleading and imprecise term 'original sin'".

Secondly, to restore meaning to suffering we have Levinas' reference to the Talmud:

"Rava, and some say Rav Hisda, said: If a person sees that suffering has befallen him, he should examine his actions. [1] Generally, suffering comes about as punishment for one's transgressions, as it is stated: "We will search and examine our ways, and return to God" (Lam 3,40). [2] If he examined his ways and found no transgression for which that suffering is appropriate, he may attribute his suffering to dereliction in the study of Torah. God punishes an individual for dereliction in the study of Torah in order to emphasize the gravity of the issue, as it is stated: "Happy is the man whom You punish, Lord, and teach out of Your law" (Ps 94,12). This verse teaches us that his suffering will cause him to return to Your law. [3] And if he did attribute his suffering to dereliction in the study of Torah, and did not find this to be so, he may be confident that these are afflictions of love, as it is stated: "For whom the Lord loves, He rebukes, as does a father the son in whom he delights" (Pr 3,12)" (Berakhot 5a-5b).

We can take this passage as a probability check: the sufferer should see her own wrongdoing as the most probable cause of her suffering (this will most often be true); if this is not so, the reason is probably that his devotion to the study of Torah falls short (these cases are added to the previous ones); and if this does not explain 
her suffering, there can only be one reason: she suffers for the sake of love. But what is the source of the suffering of a person who suffers for the sake of the suffering of another? (1) sins of commission: I can suffer when I see the great pain that I unjustly caused in the other; (2) sins of omission: I can suffer because my negligence in the study of Scripture has kept me from seeing clearly the other's need or pain calling for my response; or (3) I suffer not because I have hurt my neighbor by commission or omission, but simply because I love her and his affliction is causing me pain. Dostoyevsky's characters are of this third kind, if they are really innocent and accept their suffering as an atonement for all.

\section{Our just suffering for the unjustified suffering of the 'migrant'}

We, too, suffer ( $a$ ) directly, when the world is hostile to us or others are unfriendly to us; or $(b)$ indirectly, when we suffer seeing others suffering. Regarding immigration, suffering comes about in both ways: migration hurts first and foremost the migrant $(a)$ but it may also affect someone else who sees the migrant in pain $(b)$. To this indirect suffering we should apply the three sources of suffering explained in the Talmud: $\left(b_{1}\right)$ a person knows she is guilty of the migrant's situation because of the actions she or her nation have taken to create the conditions for the immigrant's exodus in the first place; $\left(b_{2}\right)$ a person who awakens from her 'dream of indifference' in which she has slept for having supported the immigrant only at a distance and through social media -'slacktivism', in human rights (Hodgood 2013: ch.5) - and feels chagrin when she realizes that she did not do what she could have done (omission); $\left(b_{3}\right)$, a person who through no fault of her own $\left(b_{1}, b_{2}\right)$ suffers for the sake of love by seeing and caring for the other who is at once victim and immigrant.

Paradoxical as it may seem, we are generally prone to type $b_{3}$ suffering than to $b_{1}$; we mean that it is easier to suffer seeing the suffering of displaced families fleeing from Syria to Lebanon by making a donation to the UNHCR than to give employment, shelter or food to a Honduran migrant who has come into our country. Why?

Levinas suggests an answer. When he indicates that "the just suffering in me for the unjustifiable suffering of the other" (Levinas 1998: 94), he seems to be referring to $b_{1}$. He also says: "for me the suffering of compassion, suffering because the other suffers, is only one aspect of a relationship that is much more complex and much more complete at the same time: that of responsibility for the other" (Levinas 1998: 107).

But how does 'suffering for the sake of the other's suffering' pertain to responsibility? "On this account, any other human being who challenges me in my self-sufficiency and complacency is for me the Other; the Other takes me out of myself. In the face of the Other I do not have recourse to abstract principles or utilitarian calculations, but instead I find that prior to an act of will I have opened up my home and given away the food I needed for myself" (Bernasconi 2018: 96).

Think of the production of narcotics in Central and South America and their consumption in the United States, the chief consumer of drugs in the world. Or think of the immigration that has taken place over the last few years from several African countries to Portugal, France, Germany, and other countries. Can Europe build a wall, cancel visas, stop ships, or deport persons from no other reason than to protect its domestic economy? In what sense is there a national identity that now holds a European nation responsible for what its former subjects have done centuries ago in its colonies, say, regarding lumber, minerals, fruit, women, slaves...? To what extent is that European country responsible for the situation of the African country that now suffers violence, insecurity, poverty and tyranny, which are the prime reasons why people flee? The $b_{3}$ situation will always be the easiest, since it assumes our disinterested, generous love; however, the $b_{1}$ situation holds us responsible and guilty before the suffering. For if we place ourselves in $b_{1}$, our action will never be enough, we will remain in debt, as St. Paul told Philemon: "you are also my debtor, and you yourself are the debt" (Phlm 19).

In the previous analysis we can see the difference between Rosenzweig's viewpoint and Levinas', since not every relation of vulnerability is one of gracious redemption $\left(b_{3}\right)$; there is also a relation of guilt $\left(b_{1-2}\right)$, and in this case I suffer justly for I know that it is I who caused the other's unjustified immigration. Levinas himself affirms that: "An ethical significance of a past which concerns me, which 'has to do with' me, which is 'my business' outside all reminiscence, all retention, all representation, all reference to a recalled present. A significance in ethics of a pure past irreducible to my present, and thus, of an originating past. An originating significance of an immemorial past, in terms of responsibility for the other man. My unintentional participation in the history of humanity, in the past of others which has something to do with me" (Levinas 1998: 150).

Several writers (Barash 2011; Lin 2014; Hayat 2009), as we know, have given us interesting hypothesis for understanding the 'immemorial past' that Levinas speaks of; we would rather offer this case in point: the migration forced by the past actions of my own country against the countries from which large numbers are now fleeing. Should I be held responsible for the ambition and greed of my forebearers? To what extent is there a national or cultural identity that links me to a past outside of my own freedom? These are open questions for which we have no answers; nevertheless, we believe that Levinas' ethics remains a valid approach to our contemporary immigration crisis. An interesting research agenda thus opens here, one combining the history of colonialism and its ethical repercussions for the present generations. This effort, we assert, must avoid both romanticizing the poor countries, which leads to release them form any responsibility for their own condition, and discharging the 
contemporary generations of former colonial countries, adducing an unbridgeable historical gap that ultimately acquits the present from the horrors committed in the past.

On the other hand, we do not support open borders (Carens 2015) as a solution to immigration issues -it might be a temporary solution but never a definitive one. We say this for three reasons. First, let us imagine that I am responsible (along with my country) for having caused a cultural, environmental, economic or civil disorder in another nation. After opening the doors of my own country to immigrants, is it no longer necessary to face the basic problem that demands restitution of the order in their homeland? People do not wish to migrate; they seek the betterment of their own country. Of course, if this is impossible, they feel they must leave for their own survival and the survival of their families. However, the first duty of a nation is to acknowledge its responsibility for its national past, wherein lies the root of the unjustifiable suffering of migrants.

A second reason has to do with the psychological harm the immigrant may suffer. This was experienced by the millions that the Second World War forced to leave their home. In L'Humanité perdue, Alain Finkielkraut reflects on Hannah Arendt's harsh words: "We have lost our home, that is, the familiarity of our everyday life. We have lost our profession, that is, the security of being useful in this world. We have lost our mother tongue, that is, our natural reactions, the simplicity of the gestures and the spontaneous expression of our feelings. We have left our fathers in the ghettos of Poland and our best friends have been murdered in the concentration camps, which means that our private lives have been broken" (Arendt 1987 in Finkielkraut 1998: 138). Along with the multiplicity of challenges that a person who is forced to leave her home faces, perhaps one of the most important is the loss of her national identity and, more intimately, of her sense of belonging to the community wherein she has spent her whole live. In the end, as Jean Ámery points out, we human beings still need stories and story-telling objects in order to make sense of our lives. Against this need of belonging, Arendt opposes the fact that the displaced person was, in the twentieth century, the most representative sociopolitical category. The drama of the immigrant that has not found, and perhaps never will find a new home, a place to belong, places us at the center of the twentieth-century drama. On the one hand, the dangers of radical nationalism and its delusional ethnopolitics; on the other, the fact that human beings need communities they belong to, something to call home in order to live fulfilled lives. It seems that only by keeping the tension between the local and the global, the familiar and the exotic, that humanity has a chance to live a fulfilled life in both intimacy and respect for diversity. A glimpse of Western arrogance arises here, for the solution cannot be to assimilate the other into the dominant culture, but to acknowledge the right of cultures to flourish on their own. Although the argument for open borders is an important moral step, the consequences of assimilation as well as the potential violence that the flight of human capital can do to poor countries remains to be properly studied.

It is worth mentioning, finally, that the dream of a world without countries or nationalities is found today not in the communist agenda but rather in the neoliberal attempt to impose a totalizing logic upon the world, a logic that creates winners and losers, causing evident suffering on the latter and, in the extreme case, forcing them to leave their countries. Thus, often the immigrant's destination is the country that to a greater or lesser extent was the cause of the environmental, political, or economic downturn that led them to immigrate in the first place. What will guarantee that the 'logic of power' or the 'logic of ambition' which provoked the immigration in the first place will not now be repeated in the victims themselves as they are introduced into a system that goes on without change? The necessity of Levinas' $b_{1}$ becomes urgent here, for adopting only a redemptive approach would lead to the continuous reproduction of the very conditions that keep the wicked system running.

For this reason, we believe that a determined, lasting, and substantial intervention is better in the area of health, employment, industry, democratization, education, business, restoring of the social fabric, and others, by those countries that have caused the harm in those people who are now living in crisis. We are not speaking of cancelling foreign debts but of undermining the roles wherein creditors become debtors, wherein vulnerability becomes hyperbole, and our own vulnerability for the other's vulnerability becomes the force behind international relations.

This subversion should also apply in those countries that in the past have suffered exploitation, since they, too, ought to learn from their past, being grateful when called for, not having resentment or wishing for reprisal; the reason is that the just suffering of one who provoked unjustifiable suffering will also teach them that they in turn have unpaid debts in and outside their country, and they should suffer justly for that other unjustifiable suffering, because, as Geddes says: "I look here at (...) the suffering of one whose vulnerability has been translated from a capacity to be wounded to the suffering that wounding inflicts" (2015: 400). Indeed, no country is exempt from being a victimizer.

\section{References}

Agamben, G. (1999). Remnants of Auschwitz. The Witness and the Archive. New York: Zone Books. Arendt, H. (1987). "Nous autres, réfugiés," La Tradition cachée, Paris: Christian Bourgois.

Barash J. A. (2011) "Memory and the Immemorial in the Philosophy of Emmanuel Levinas". In: Dimitrova, M. (ed). In Levinas’ Trace. Newcastle upon Tyne: Cambridge Scholars Publishing. 
Bernasconi, R. (2018). “Levinas, social vulnerability, and the logic of South African racism”, Suomen Antropologi, $43 / 3,91-101$.

Carens, J. (2015). The Ethics of Immigration. New York: Oxford University Press.

Dostoyevsky, F. (2009), The Brothers Karamazov, Garnett, C. (trad.) New York: The Lowell Press.

Finkielkraut, A. (1998). A humanidad Perdida. Ensayo sobre el siglo XX. Barcelona: Anagrama.

Geddes, J. L. (2015). "Violence and Vulnerability: Kafka and Levinas On Human Suffering". Literature and Theology, 29/4, 400-414.

Hayat, P. (2009). “La critique de la prééminence du présent. Subjectivité et «entretemps» d'après Levinas". Revue Philosophique de Louvain, 107/2, 301-317.

Hodgood, S. (2015). The Endtimes of Human Rights. New York: Cornell University Press.

Husserl, E. (2009). "Wert des Lebens. Wert der Welt. Sittlichkeit (Tugend) und Glückseligkeit <Februar 1923>", Ullrich Melle (ed.), Husserl Studies, Vol. 13, no. 3, Kluwer Academic Publishers 1997, pp. 201-235; translated to Spanish: "Valor de la vida. Valor del mundo. Moralidad (virtud) y felicidad" Iribarne, J. (trad.). Acta Fenomenológica Latinoamericana, Vol. III, Lima 2009, 789-821.

Levi, P. (1997). Conversazioni e interviste. Turin: Einaudi.

Levinas, E. (1998). Entre nous: on thinking-of-the-other, New York: Columbia University Press.

Levinas E. (1998b), "Transcendence and Evil" Postface to: Nemo, P. Job and the excess of evil, Pittsburgh: Duquesne University Press.

Levinas, E. (2000), God, death, and time, Stanford: Stanford University Press.

Lin, Y. (2014). Levinas Faces Biblical Figures. Lanham: Lexington Books.

Ratzinger, J. (1995). In the Beginning. A Catholic Understanding of the Story of Creation and the Fall. Grand Rapids: William B. Eerdmans.

Serrano de Haro, A. (2010). "Dos planteamientos acerca del mal y el Holocausto: Hannah Arendt, Emil Fackenheim” In: González, M. (comp.) Filosofia y dolor, Madrid: Tecnos.

Talmud (Babylonian): www.halakhah.com

Talmud (Yerushalmi): www.mechon-mamre.org 